\title{
Factories Europe, Asia, and North America as the main production centres in the 21st century
}

\author{
Aleksandra Nacewska-Twardowska
}

\section{A B S T R A C T}

Objective: The paper aims to present how the relations between countries in global value chains (GVC) changed at the beginning of the 21st century.

Research Design \& Methods: For this purpose, we propose two approaches. The first focuses on presenting data in the form of a matrix of trade flows in domestic value added in intermediate products. The second is related to analyzing the GVC indicator (GVC participation). The analysis uses data from the OECD and WTO Trade in Value Added databases.

Findings: The global economy still is not unified. I indicate the existence of 3 major supply chain blocks, which can be called Factories: Factory Europe, Factory Asia, and Factory North America. In the trade of intermediate products, the primary relationships are inter-regional rather than intra-regional. Some countries act as hubs. Germany and the US play the role of regional supply hubs, while China assumes the role of the world supply hub, becoming the largest exporter and importer in GVC activities.

Contribution \& Value Added: The use of export data in value-added terms instead of gross export data indicates significant differences in the description of world economy trade relations.

\begin{tabular}{ll}
\hline Article type: & research paper \\
& global value chains (GVC); Factories; major supply chain blocks; \\
Keywords: & gross exports; value-added exports; TiVA \\
& F13, F15, F6 \\
JEL codes: & \multicolumn{2}{c}{ Article received: 1 February 2020 } & Articlepted: 31 March 2020 \\
\hline
\end{tabular}

\section{Suggested citation:}

Nacewska-Twardowska, A. (2020). Factories Europe, Asia, and North America as the main production centers in the 21st century. International Entrepreneurship Review (previously published as International Entrepreneurship / Przedsiębiorczość Międzynarodowa), 6(1), 63-76. https://doi.org/10.15678/IER.2020.0601.04 


\section{INTRODUCTION}

Technological progress, along with the fragmentation of production, has led to increased links between economies. As a result, since the end of the 20th century, financial and commercial connections between countries around the world have increased faster than ever before. Economic liberalization, as promoted by major economies and international organizations, favored these changes. The increase in transport possibilities and distance production management meant that, due to price differences in raw material and labor costs, interest in materials and semi-finished products from other countries increased. The effect of these changes has shaped the world economy.

However, the world economy is not stable. The above adjustments are taking place at an ever-faster pace, and, as a result, financial and economic connections between countries are constantly changing. Individual countries adapt their internal policies to the requirements of a transforming world and, in turn, influence other countries. This dynamic structure is continually shifting. In such conditions, individual countries and regions change their position and how they participate in the global economy.

The paper aims to present how the relations between countries in global value chains (GVC) transformed at the beginning of the 21st century. In the literature, one can often find the view that the increase in trade links led to the formation of a unified economy. The analysis of trade data suggests, however, that the global economy consists of trade and production blocks in which individual entities cooperate (see, for example, Baldwin, 2008; Baldwin \& Lopez-Gonzales, 2015; Behar \& Freund, 2011; Inomata, 2017; Li et al., 2019; Miroudot \&Nordstrom, 2019). These trade and production blocks are often called supply chain blocks, and they are also known as Factories.

Analysis of data covering trade exchange shows how relations within and between Factories are shaped. This issue has become particularly interesting in the context of new ways of presenting trade data. Flows of value added in imports and exports make it possible to indicate the real impact of the share of individual countries in exports. This is particularly important in the context of production fragmentation and the occurrence of the 'double counting' of trade.

This paper argues that despite increasing production and trade interdependencies between countries around the world, most trade connections still exist among countries in the direct vicinity. These countries create factories that are connected by regional supply hubs. The analysis of real trade connections is achievable with the use of data on value added trade. The analysis shows how relationships in GVCs are shaped. In this paper, I propose two research methods to look into the relationships within and between Factories. The first focuses on presenting data in the form of a matrix of trade flows in domestic value added in intermediate products. The second is related to analyzing the GVC indicator (GVC participation). The analysis uses data from the OECD and WTO Trade in Value Added databases. Due to the availability of data, the study will be limited to 2005-2015.

The rest of the paper is organized as follows. The next section, entitled Material and Methods, presents fundamental information about GVCs and the trade in value added. This is followed by Results and Discussion, which is divided into two parts: Major supply chains within regions, and Changes in links between Factories. The former describes relationships within the three largest Factories. It presents data on intra-block trade in 
2005 and 2015, which makes it possible to show the changes that took place in economic relations within the blocks at the beginning of the 21st century. The second part illustrates the changes that occurred during the same period in relationships between blocks. The final section presents conclusions.

\section{MATERIAL AND METHODS}

\section{Global value chains}

Due to the fragmentation in world production, world trade is increasingly linked to global production chains. Global production chains can be defined as all activities that enterprises must perform to create a product. The concept of production chains defined in this way can be combined with the concept of global value chains. In the first decade of the 21st century, researchers agreed that the terms global commodity chains, value chains, value systems, production networks, and value networks, describe similar conceptions (Gereffi et al., 2001).

The activities undertaken within the framework of value chains should include the concept phase as well as all activities that make it possible to deliver the product to the final recipient (De Backer\& Miroudt, 2013). Value chains also include all activities connected with the final good after delivery to the final consumer. Automotive corporations are an easy to understand example. In addition to delivering ready-made vehicles, they also provide repair and maintenance services through cooperating dealers. Thus, a typical value chain does not end with simple sales, but it also includes after-sales services. It consists of many activities: design, production, marketing, distribution, and finally, support for the customer.

The globality of the phenomenon is connected with the spread of production between many countries. According to the World Trade Organization, global value chains define the combined production of goods or services in at least two countries (World Trade Organization [WTO], 2014). Simultaneously the term 'value' is combined with adding product value in subsequent production phases.

Due to value layers being added, the problem of correctly presenting and measuring international trade has arisen. Increasingly, in the global economy, we are dealing with a combination of exports with earlier imports. If you want to export, you must first import. The introduction of many stages of production has led to one product being repeatedly exported and imported in various production states. The result is the doublecounting of trade. This phenomenon is presented in a simplified way in Figure 1.

Figure 1 presents the production diagram of a product in six different economies. During production in the subsequent countries, new value layers are added to the product. Some of them are the result of domestic production. Some, however, are materials, semi-finished products, or services that first had to be imported in advance. Formed in this way, the global value chain allows the production of a finished product. The schema analysis makes it possible to show the main problem related to the doublecounting of exports in traditional trade statistics. In this approach, the global export related to the manufactured product is 210 , when, in fact, the export of value added generated in all countries is 100.As a consequence, traditional trade statistics overestimated world trade more than twice. 


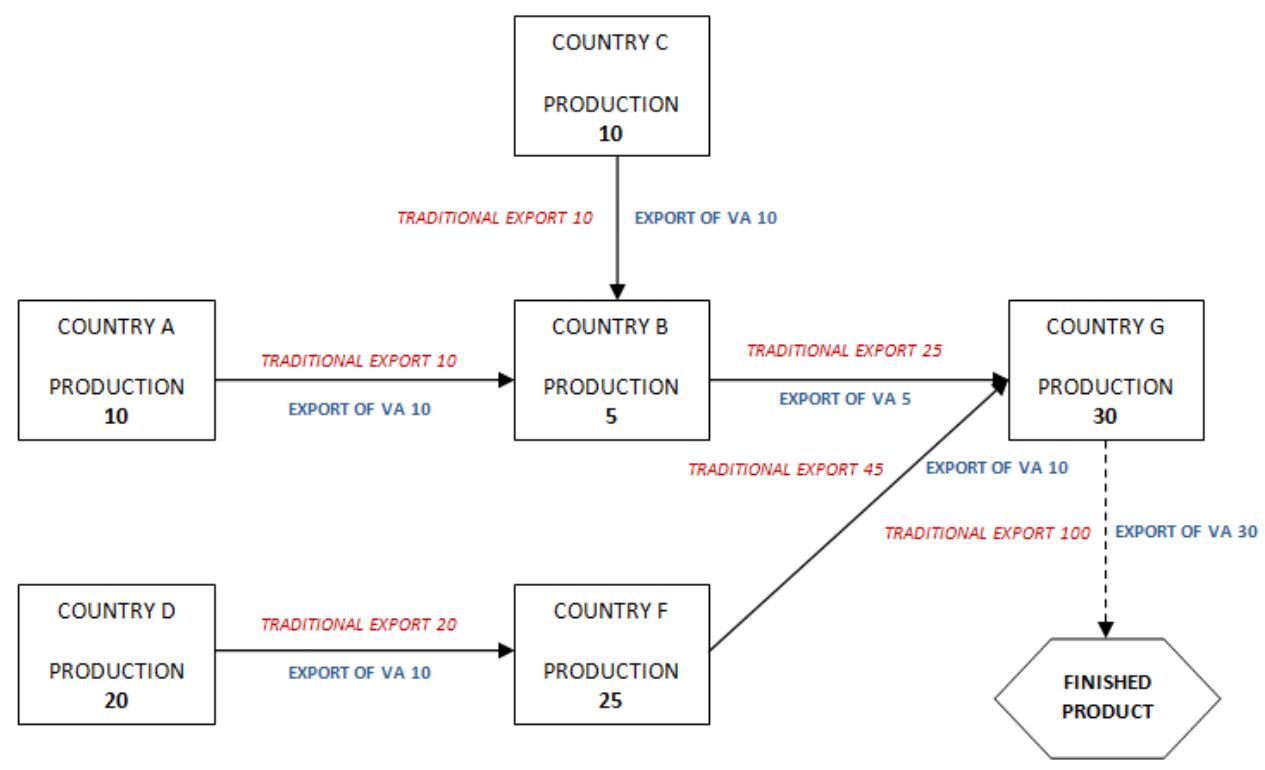

Figure 1. An example of a global value chain

Source: own elaboration.

\section{Value added trade}

Analyzing trade in terms of added value shows the real links between economies more accurately. It allows us to specify how much value added generated in a given country goes to another country (Ambroziak, 2018a). The problem, however, lies in the statistical data. It is necessary to use international input-output tables, which are very difficult to construct. The input-output approach of trade flows in value-added terms was described by, inter alia, Koopman et al. (2010), Stehrer et al. (2012), Folfas (2016), and Ambroziak (2018b). The OECD and WTO presented a conceptual framework for tracking value-added at the beginning of the 21st century. It is possible to decompose any particular product with value $\mathrm{V} p$ into the value added generated in country $i$ such that the total value of:

$$
V^{p}=\sum_{i} V A_{i}^{p}
$$

This simple formula becomes more complicated when aggregating up for a group of products or the whole economy. As a result, it is necessary to use data that has been aggregated to some extent. However, the use of the international input-output table makes it possible to decompose gross trade into value added components (Figure 2).

Figure 2 presents the division of gross export (measured traditionally) for parts related to value added trading: FVA - foreign value added content of exports, and DVA - domestic value added. Value added produced and exported by the reporting country is divided into three fractions (Organisation for Economic Co-operation and Development [OECD], 2016):

- Domestic value added sent to the consumer economy corresponds to the domestic value added embodied either in the final or intermediate goods or services that are directly consumed by the importing economy. 
- Domestic value added sent to third economies represents the domestic value added contained in intermediates (goods or services) exported to a first economy that re-exports them to a third economy as embodied in other goods or services.

- Domestic value added re-imported in the economy outlines the domestic value added of exported intermediates or inputs that are sent back to the economy of origin as embodied in other intermediates and used to produce exports.

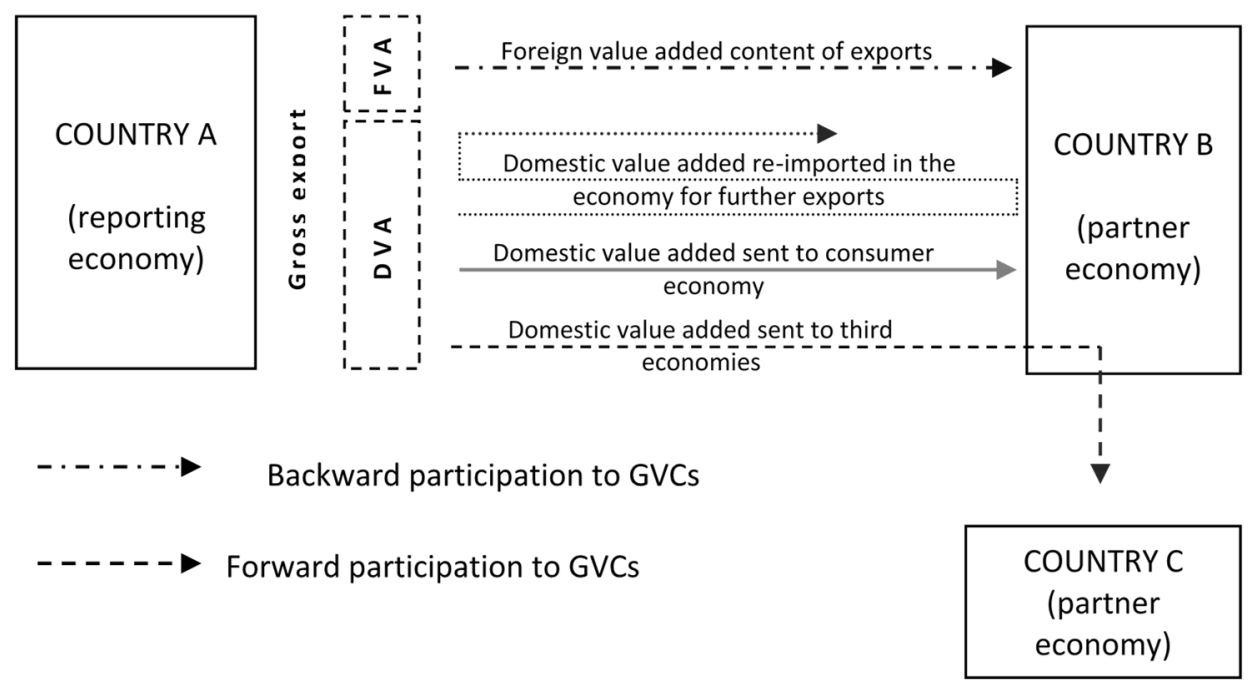

Figure 2. Division of gross exports into domestic and foreign value added components along with links up and down the supply chain Source: own elaboration based on (OECD, 2016).

\section{RESULTS AND DISCUSSION}

\section{Major supply chains within regions}

The concept of global value chains assumes the creation of links between countries that are not necessarily located geographically close. Research on trade relations, however, indicates the functioning of three regional blocks in which links between countries are inter-regional rather than intra-regional (Johnson \& Noguera, 2012). These regions can be called Factories and, as Baldwin and Lopez-Gonzales (2015) write, we can distinguish:

- Factory Asia,

- Factory Europe,

- Factory North America.

It is possible to indicate these Factories by presenting trade links in matrix form. Each element of the matrix represents the links between the two countries. To analyze GVC-related exports, it is necessary to separate the value of domestic value added in intermediate goods and services from a country's gross exports. This makes it possible to show the share of a country's exports that consist of domestic value added that is 
destined for further production within direct partners' economies - either to meet the partners' final demands or to be embodied in exports by direct partners (OECD, 2019).

Each element of the matrix (Tables1 and 2) shows the domestic value added in gross exports of intermediate products exported by source country (the nation row) to partner country (the nation column) as a share of total world value added in gross exports of intermediate products. To indicate the most important relationships, I have zeroed out any bilateral flows that are less than $0.01 \%$ of the share in the global trade of value added in intermediate products. The rows and columns in the matrix are arranged to reflect regions: European Union along with the European Economic Area, then Asia and North America. Finally, there are countries from South America and Africa.

\section{Factory Europe}

In the upper left corner of the matrices in Tables 1 and 2, a rectangle with European Union countries is presented along with the European Economic Area countries. Analyzing the relationships of the countries in rows, the countries with the largest share in the export of intermediate products are Germany and France. However, their share in the export of domestic value added in intermediate products in Europe globally decreased between 2005 and 2015. A similar trend can be seen in other countries in the region. Poland and the Czech Republic stand out against this tendency, significantly increasing their share in the export of domestic value added in intermediate products to Germany.

Analyzing the countries by column shows which ones mostly import foreign value added in intermediate products. In the case of Factory Europe, Germany is such a country. It is the largest export market of domestic value added in intermediate products for other European countries. Analyzing the position of Germany in a broader context, it can be pointed out that it is a country in Europe that acquires the most intermediate products for internal production. To sum up Factory Europe, inter-regional relations prevail.

\section{Factory Asia}

Interesting changes have taken place inside Factory Asia. It is represented by a rectangle in the middle of the matrix in Tables 1 and 2. Analyzing source countries of domestic value added in intermediate products, there is a noticeable decrease in the importance of Japan as an exporter for South Korea, Taiwan, and Thailand. Over the past 10 years, China's exports have increased significantly to India and South Korea. At the same time, almost all countries increased their exports of domestic value added in intermediate products to China.

Japan's share as a recipient country of exports from other Factory Asia countries also decreased in the analyzed period. The most significant increase in the share was noticeable in China, but also in India and South Korea. Summarizing the changes in Factory Asia, the shift in inter-regional trade from Japan to China is noticeable.

\section{North America}

In the North America Factory, the leading trade partner in domestic value added in intermediate products is the USA. On the one hand, it is the largest exporter of domestic value added intermediate products to Canada and Mexico. At the same time, both Canada and Mexico mainly export domestic value added of intermediate products to the USA. At the beginning of the 21st century, there was a decrease in inter-regional trade, but still, Factory Asia is the region that internally cooperates the most (Tables 1 and 2). 
Table 1. Domestic value added in gross exports of intermediate products as a share of total world value added in gross exports of intermediate products in selected countries ${ }^{1}$ in 2005

\begin{tabular}{|c|c|c|c|c|c|c|c|c|c|c|c|c|c|c|c|c|c|c|c|c|c|c|}
\hline & $\stackrel{5}{2}$ & 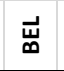 & $\underset{\S}{\nwarrow}$ & 岂 & $\overrightarrow{\underline{\underline{x}}}$ & $\stackrel{\Xi}{E}$ & 号 & 鿖 & 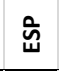 & $\sum_{n}$ & 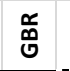 & 岌 & 론 & $\underline{\imath}$ & $\begin{array}{l}\stackrel{\circ}{0} \\
\stackrel{1}{*}\end{array}$ & za & $\sum_{k}^{z}$ & $\stackrel{\nwarrow}{\underline{1}}$ & 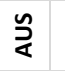 & $\frac{z}{8}$ & $\stackrel{\underset{\mathbf{L}}{\Sigma}}{ }$ & ธุ \\
\hline AUT & & & & 0.81 & & & & & & & & & & & & & & & & & & \\
\hline BEL & & & 0.340 & 0.26 & & & 0.17 & & & & 0.14 & & & & & & & & & & & \\
\hline CZE & & & & 0.37 & & & & & & & & & & & & & & & & & & \\
\hline DNK & & & & & & & & & & 0.15 & & & & & & & & & & & & \\
\hline FRA & & 0.12 & & 0.59 & & 0.45 & & & 0.34 & & 0.36 & & & & & & & & & & & 0.34 \\
\hline DEU & 0.16 & & 0.60 & & & $0.44 \mathrm{C}$ & 0.12 & & 0.15 & & $0.36 \mid 0$ & 0.18 & & & & & & & & & & 1.02 \\
\hline HUN & & & & 0.19 & & & & & & & & & & & & & & & & & & \\
\hline IRL & & & & & & & & & & & 0.23 & x & & & & & & & & & & 0.40 \\
\hline ITA & & & 0.490 & 0.40 & & & & & 0.17 & & 0.17 & & & & & & & & & & & 0.38 \\
\hline NLD & & 0.26 & 0.110 & 0.62 & & & & & & & 0.20 & & & & & & & & & & & 0.20 \\
\hline POL & & & & 0.46 & & & & & & & & & & & & & & & & & & \\
\hline PRT & & & & & & & & & 0.22 & & & & & & & & & & & & & \\
\hline ESP & & & 0.430 & 0.20 & & 0.13 & & 0.12 & & & 0.22 & & & & & & & & & & & \\
\hline SWE & & & & 0.12 & & & & & & & & i & & & & & & & & & & 0.18 \\
\hline GBR & & & 0.270 & 0.510 & 0.18 & 0.13 & & & 0.12 & & & & & & & & & & & & & 1.35 \\
\hline NOR! & & & 0.220 & 0.11 & & & & & & & 0.74 & & & & & & & & & & & 0.12 \\
\hline CHE : & & & & 0.41 & & & & & & & & & & & & & & & & & & 0.15 \\
\hline ISR & & & & & & & & & & & & & & & & & & & & & & 0.26 \\
\hline RUS & & & & 0.14 & & 0.12 & & & & & & & 0.17 & & & & & & & & & 0.18 \\
\hline CHN & & & & & & & & & & & & & & \multicolumn{4}{|c|}{0.270 .89} & & & & & 3.79 \\
\hline HKG & & & & & & & & & & & & & 0.35 & & & & & & & & & \\
\hline IND & & & & & & & & & & & & & & & & & & & & & & 0.51 \\
\hline IDN & & & & & & & & & & & & & & & & 0.42 & & & & & & 0.11 \\
\hline KAZ & & & & & & & & & & & & & & & & & & & & & & \\
\hline KOR & & & & & & & & & & & & & 1.91 & & & 0.19 & & & & & & 0.60 \\
\hline MYS & & & & & & & & & & & & & 0.18 & & & & & & & & & 0.20 \\
\hline JPN & & & & & & & & & & & & & 1.70 & & 0.61 & & \multicolumn{2}{|c|}{$\begin{array}{lll}0.40 & 0.10\end{array}$} & & & & 3.11 \\
\hline \multicolumn{23}{|l|}{ PHL } \\
\hline SAU & & & & & & & & & & & & & $0.11 \mathrm{c}$ & 0.54 & 0.16 & 0.43 & & & & & & 1.05 \\
\hline SGP & & & & & & & & & & & & & 0.11 & & & & & & & & & \\
\hline TWN & & & & & & & & & & & & & 2.16 & & & 0.11 & & & & & & 0.38 \\
\hline THA & & & & & & & & & & & & & 0.13 & & & 0.13 & & & & & & 0.18 \\
\hline \multicolumn{23}{|l|}{ VNM } \\
\hline \multicolumn{23}{|l|}{ AUS } \\
\hline NZL & & & & & & & & & & & & & & & & & & & 0.10 & & & \\
\hline CAN & & & & & & & & & & & & & & & & & & & & & & 22.41 \\
\hline MEX & & & & & & & & & & & & & & & & & & & & & & 9.71 \\
\hline USA & & & 0.120 & 0.25 & & & & & & & 0.30 & & 0.26 & & 0.19 & 0.67 & & & & 2.831 & 1.30 & \\
\hline BRA & & & & & & & & & & & & & & & & & & & & & & 0.70 \\
\hline CHL & & & & & & & & & & & & & 0.10 & & & & & & & & & 0.12 \\
\hline $\mathrm{COL}$ & & & & & & & & & & & & & & & & & & & & & & 0.60 \\
\hline PER & & & & & & & & & & & & & & & & & & & & & & 0.22 \\
\hline ZAF & & & & & & & & & & & & & & & & & & & & & & \\
\hline
\end{tabular}

Source: own elaboration based on TiVA Database (OECD, 2020).

\footnotetext{
${ }^{1}$ Explanation of acronyms: AUT - Austria; BEL - Belgium; CZE - Czech Republic; DNK - Denmark; FRA - France; DEU - Germany; HUN - Hungary; IRL - Ireland; ITA - Italy; NLD - Netherlands; POL - Poland; PRT - Portugal; ESP - Spain; SWE - Sweden; GBR - United Kingdom; NOR - Norway; CHE - Switzerland; ISR - Israel; RUS - Russian Federation; CHN - China (People's Republic of); HKG - Hong Kong (China); IND - India; IDN - Indonesia; KAZ Kazakhstan; KOR - Korea; MYS - Malaysia; JPN - Japan; PHL - Philippines; SAU - Saudi Arabia; SGP - Singapore; TWN - Chinese Taipei; THA - Thailand; VNM - Viet Nam; AUS - Australia; NZL - New Zealand; CAN - Canada; MEX -Mexico; USA - United States; BRA - Brazil; CHL - Chile; COL - Colombia; PER - Peru; ZAF - South Africa.
} 
Table 2. Domestic value added in gross exports of intermediate products as a share of total world value added in gross exports of intermediate products in selected countries in 2015

\begin{tabular}{|c|c|c|c|c|c|c|c|c|c|c|c|c|c|c|c|c|c|c|c|c|c|}
\hline & $\stackrel{5}{2}$ & $\vec{\varpi}$ & $\underset{\dddot{\sharp}}{\stackrel{\nwarrow}{4}}$ & 岂 & $\overrightarrow{\underline{\underline{ }}}$ & 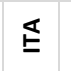 & 号 & 言 & जे & 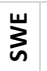 & $\begin{array}{l}\text { 寕 } \\
\text { }\end{array}$ & 곤 & @ & $\begin{array}{l}\text { o̊ } \\
\text { on }\end{array}$ & za & $\sum_{k}^{2}$ & $\stackrel{\nwarrow}{I}$ & $\stackrel{n}{\gtrless}$ & z & $\stackrel{\underset{\mathbf{L}}{\Sigma}}{ }$ & ธิ \\
\hline AUT & & & & 0.68 & & & & & & & & 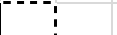 & & & & & & & & & \\
\hline BEL & & & $0.26 c$ & 0.21 & & & 0.14 & & & & & & & & & & & & & & \\
\hline CZE & & & & 0.39 & & & & & & & & 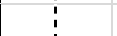 & & & & & & & & & \\
\hline DNK & & & & & & & & & & & & & & & & & & & & & \\
\hline FRA & & 0.12 & & 0.49 & & 0.16 & & & 0.14 & & 0.22 & 0.16 & & & & & & & & & 0.20 \\
\hline DEU & 0.12 & & 0.45 & & & 0.16 & & & & & $0.29 \mid c$ & $0.16: 0.53$ & & & & & & & & & 0.71 \\
\hline HUN & & & & 0.17 & & & & & & & & 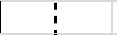 & & & & & & & & & \\
\hline IRL & & & & & & & & & & & 0.20 & i & & & & & & & & & 0.34 \\
\hline ITA & & & $0.21 c$ & 0.29 & & & & & & & & $\vdots$ & & & & & & & & & 0.26 \\
\hline NLD & & 0.15 & & 0.52 & & & & & & & & & & & & & & & & & 0.11 \\
\hline POL & & & & 0.56 & & & & & & & & $\vdots$ & & & & & & & & & \\
\hline PRT & & & & & & & & & 0.12 & & & 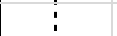 & & & & & & & & & \\
\hline ESP & & & $0.29 c$ & 0.17 & & & & & & & 0.12 & ! & & & & & & & & & \\
\hline SWE & & & & & & & & & & & & 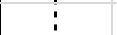 & & & & & & & & & \\
\hline GBR & & & $0.20 \mathrm{C}$ & 0.310 & 0.18 & & & & & & & ! & & & & & & & & & 0.86 \\
\hline NOR & & & & 0.21 & & & & & & & 0.33 & ; & & & & & & & & & \\
\hline CHE & & & & 0.37 & & & & & & & & & & & & & & & & & 0.26 \\
\hline ISR & & & & & & & & & & & & & & & & & & & & & 0.34 \\
\hline RUS & & & & 0.23 & & 0.22 & & & & & & 0.53 & & & & & & & & & 0.11 \\
\hline CHN & & & & 0.14 & & & & & & & & & 0.190 & $0.49 \mathrm{c}$ & 0.75 & & & & & 0.18 & 6.15 \\
\hline HKG & & & & & & & & & & & & 0.33 & & & & & & & & & \\
\hline IND & & & & & & & & & & & & 0.12 & & & & & & & & & 0.89 \\
\hline IDN & & & & & & & & & & & & 0.32 & 0.15 & & 0.19 & & & & & & \\
\hline KAZ & & & & & & & & & & & & 0.14 & & & & & & & & & \\
\hline KOR & & & & & & & & & & & & 4.49 & & & & & & & & & 0.44 \\
\hline MYS & & & & & & & & & & & & 0.71 & & & & & & & & & \\
\hline JPN & & & & & & & & & & & & 2.64 & & 0.25 & & 0.13 & & & & & 1.21 \\
\hline PHL & & & & & & & & & & & & 0.35 & & & & & & & & & 0.10 \\
\hline SAU & & & & & & & & & & & & 0.76 & 0.240 & 0.19 & & 0.11 & & & & & 0.45 \\
\hline SGP & & & & & & & & & & & & 0.29 & & & & & & & & & \\
\hline TWN & & & & & & & & & & & & 4.09 & & & & & & & & & 0.18 \\
\hline THA & & & & & & & & & & & & 0.51 & & & & & & & & & 0.13 \\
\hline VNM & & & & & & & & & & & & 0.19 & & & & & & & & & 0.14 \\
\hline AUS & & & & & & & & & & & & 2.64 & & & 0.39 & & & & & & \\
\hline NZL & & & & & & & & & & & & 0.11 & & & & & & & & & \\
\hline CAN & & & & & & & & & & & & 0.20 & & & & & & & & & 14.52 \\
\hline MEX & & & & & & & & & & & & & & & & & & & & & 7.64 \\
\hline USA & & & $0.11 \mathrm{c}$ & 0.22 & 0.11 & & & & & & 0.20 & 1.91 & & $0.18 \mathrm{C}$ & 0.35 & & & & 2.11 & 1.18 & \\
\hline BRA & & & & & & & & & & & & 0.80 & & & & & & & & & 0.40 \\
\hline CHL & & & & & & & & & & & & 0.55 & & & & & & & & & \\
\hline $\mathrm{COL}$ & & & & & & & & & & & & & & & & & & & & & 0.54 \\
\hline PER & & & & & & & & & & & & 0.25 & & & & & & & & & \\
\hline ZAF & & & & & & & & & & & & 0.32 & & & & & & & & & \\
\hline
\end{tabular}

Source: own elaboration based on TiVA Database (OECD, 2020).

\section{Changes in links between Factories}

The changes that have occurred in the export of domestic value added in intermediate products between 2005 and 2015 are also presented in Table 3. The matrix cells in which there is a decrease in shares between 2005 and 2015 are marked in red; an increase is 
marked in green. Countries with the largest number of connections between different regions are the USA, China, and Germany. They are regional supply hubs that are responsible for intra-regional trade in domestic value added in intermediate products.

The beginning of the 21st century is characterized primarily by the growing importance of China as the leading centre to which other countries export their semi-finished products. From Factory Europe, the main exporter is Germany and then France; from Factory North America, it is the USA and, to a lesser extent, Canada. In addition to China, several countries from South America (Brazil, Chile, Peru) and also South Africa, Australia, and New Zealand export domestic value added in intermediary products.

Between 2005 and 2015, the USA reduced the share of domestic value added imports in intermediate products from most partners, with the exception of Switzerland, Israel, China, India, the Philippines, and Vietnam. At the same time, as an exporter of domestic value added in intermediate products, the US's share also fell. An increase appeared only in trade with China and Ireland. This demonstrates the relative decline in the importance of the US in global value chains.

In Factory Europe, Germany is primarily associated with other Factories. As an exporter of domestic value added in intermediate products, it trades mainly with China and the United States. However, it should be emphasized that trade with the latter decreased at the beginning of the 21st century. In Europe in 2015, in addition to Germany, the United Kingdom, Ireland, Italy, Switzerland, and France had trade relations above $0.1 \%$ in the global trade of domestic value added in intermediate products from the USA. However, in the analyzed period, the share of these countries in intra-regional trade decreased significantly.

The second approach to present links within and between Factories is to analyze the GVC participation index of countries in inter- and intra-regional trade. Fundamental indicators were introduced by Koopman et al. (2010) and the United Nations Conference on Trade and Development (UNCTAD, 2013). They proposed a general GVC participation index:

$$
G V C_{\text {participation }}=\frac{F V A+I D V A}{\text { Export }_{\text {gross }}}
$$

It is the sum of foreign value added in exports and indirect domestic value added in relation to gross exports. The larger the indicator, the higher the country's share in the global value chain.

In connection with extending international input-output tables, it is now possible to use the information on domestic value added in intermediate products instead of indirect domestic value added. This approach makes it possible to capture all links within the GVC more accurately:

$$
G V C_{\text {participation }}=\frac{F V A+D V A_{\text {intermediate products }}}{\text { Export }_{\text {gross }}}
$$

where (OECD, 2019):

$$
\text { Export }_{\text {gross }}=\sum_{\mathrm{p}} \mathrm{EXGR}_{\mathrm{c}, \mathrm{i}, \mathrm{p}}
$$

Country c's total gross exports for industry I are directly calculated from the OECD's annual Inter-Country Input-Output tables by summing the exports of intermediate goods and services and the exports of final demand goods and services.

$$
\mathrm{FVA}_{\mathrm{c}, \mathrm{i}}=V_{c} B_{c} E X G R_{c, i}
$$


Table 3. Change in domestic value added in gross exports of intermediate products as a share of total world value added in gross exports of intermediate products in selected countries between 2005 and 2015

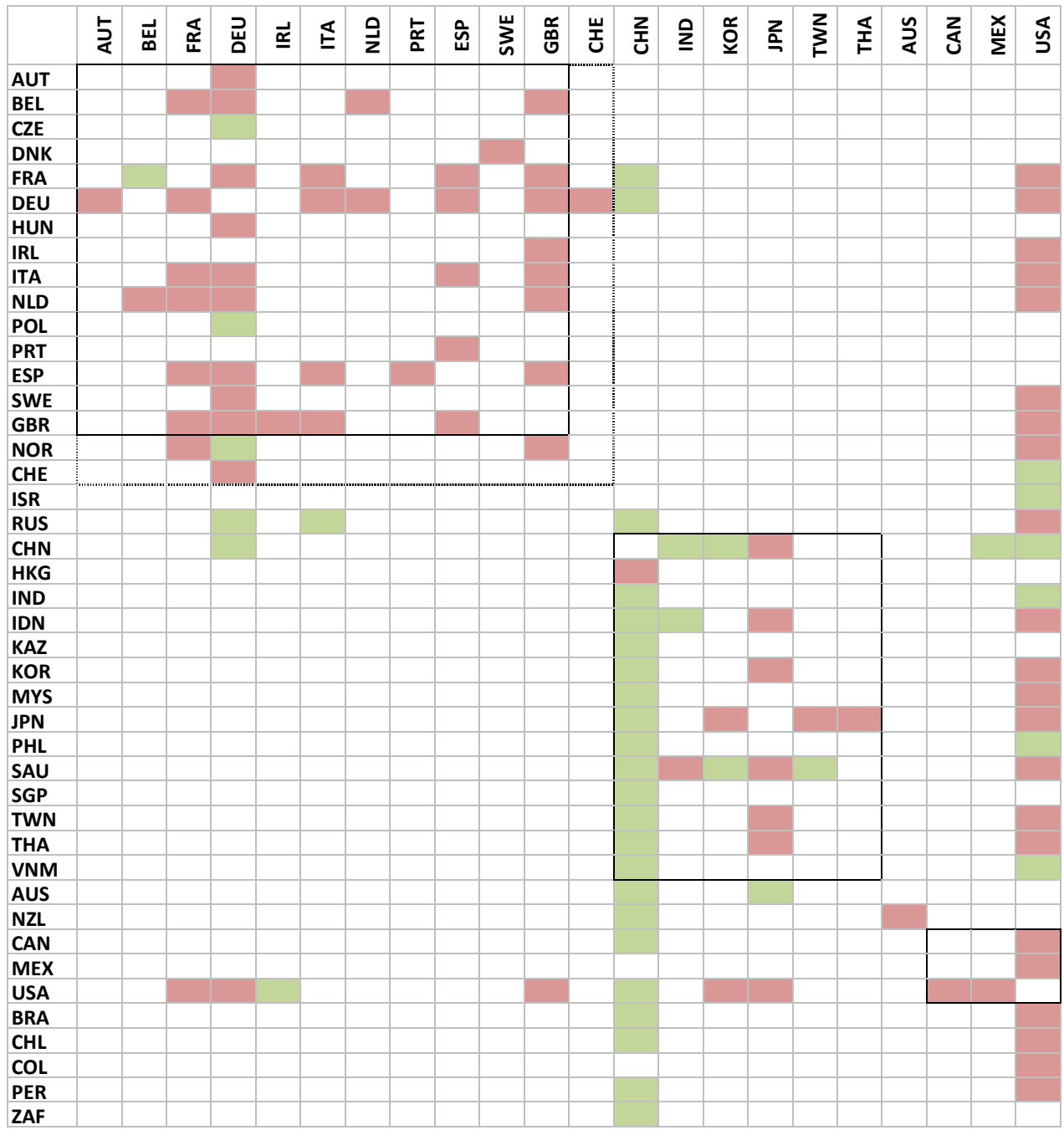

Notes: The matrix cells in which there is a decrease in the years 2005-2015 are marked in red; an increase is marked in green. Countries from Figures 3 and 4 are analyzed.

Source: own elaboration based on TiVA Database (OECD, 2020).

The foreign value added content of gross exports captures the value of imported intermediate goods and services that are embodied in a domestic industry's exports.

$$
\mathrm{DVA}_{\mathrm{c}, \mathrm{i}, \mathrm{p}}=V_{c} B_{c, c} E X G R_{c, i, p}
$$

The domestic value added content of exports, by industry $i$ in country/region $c$ to partner country/region $p$, represents the exported value added that has been generated anywhere in the domestic economy. 
For:

$\mathrm{V}$ - value added to output ratio, where $v_{i}^{p}=w_{i}^{p} / x_{i}^{p}$ is the ratio of value added to gross output by industry $i$ in country $p$;

B - Leontief inverse, or "output multipliers", $B=(I-A)^{-1}$, where the element bijps shows the direct and indirect requirements of inputs from industry $i$ in country $p$ for the production of one unit of output for demand by industry $j$ in country $s$.

Figure 3 presents changes in Factories and their participation by geographic region in three major supply chain blocks and the rest of the world (ROW). The decomposition across regions in each Factory is represented by two bars for the years 2005 and 2015.

\section{Factory Europe}

Among all the analyzed supply chain blocks, Factory Europe is characterized by the largest share of inter-regional trade in total GVC participation. However, this share decreased by almost $10 \%$ in the analyzed period. As a result, the importance of inter-regional trade with Factory Asia and ROW increased, while the importance of Factory North America remained unchanged.

\section{Factory Asia}

Although Factory Asia had the most intra-regional trade in total GVC participation in 2005, the importance of other regions dropped slightly in 2015. The decrease in links under GVC can be seen primarily in relation to Factory North America and Factory Europe.

\section{Factory North America}

As in the case of Europe, in Factory North America, the share of inter-regional trade in total GVC participation decreased. At the same time, the relationship between America and Europe decreased. However, the links between GVC and Factory Asia and ROW became more important (relative growth of approximately $51 \%$ and $43 \%$ in 2015 , respectively, compared to 2005).

\section{CONCLUSIONS}

In this paper, I presented how world production changed and influenced global production chains at the beginning of the 21st century. To illustrate this change, I used data on domestic value added in intermediate products. Thanks to the presentation of data in the matrix, in which countries have been geographically arranged, three main production centers - Factories - can be distinguished.

Analyzing the data indicates that international trade in intermediate products is primarily inter-regional, not global. Most intermediate product trading takes place inside major supply chain blocks (Factories). With the spread of economic integration in the region, inter-regional GVC connections intensify. In Europe and North America, however, there is a noticeable trend in the increasing internationalization of production chains, because the share of inter-regional exchange had decreased in 2015 compared to 2005. The opposite trend is true in Asia, where inter-regional trade increased slightly. 

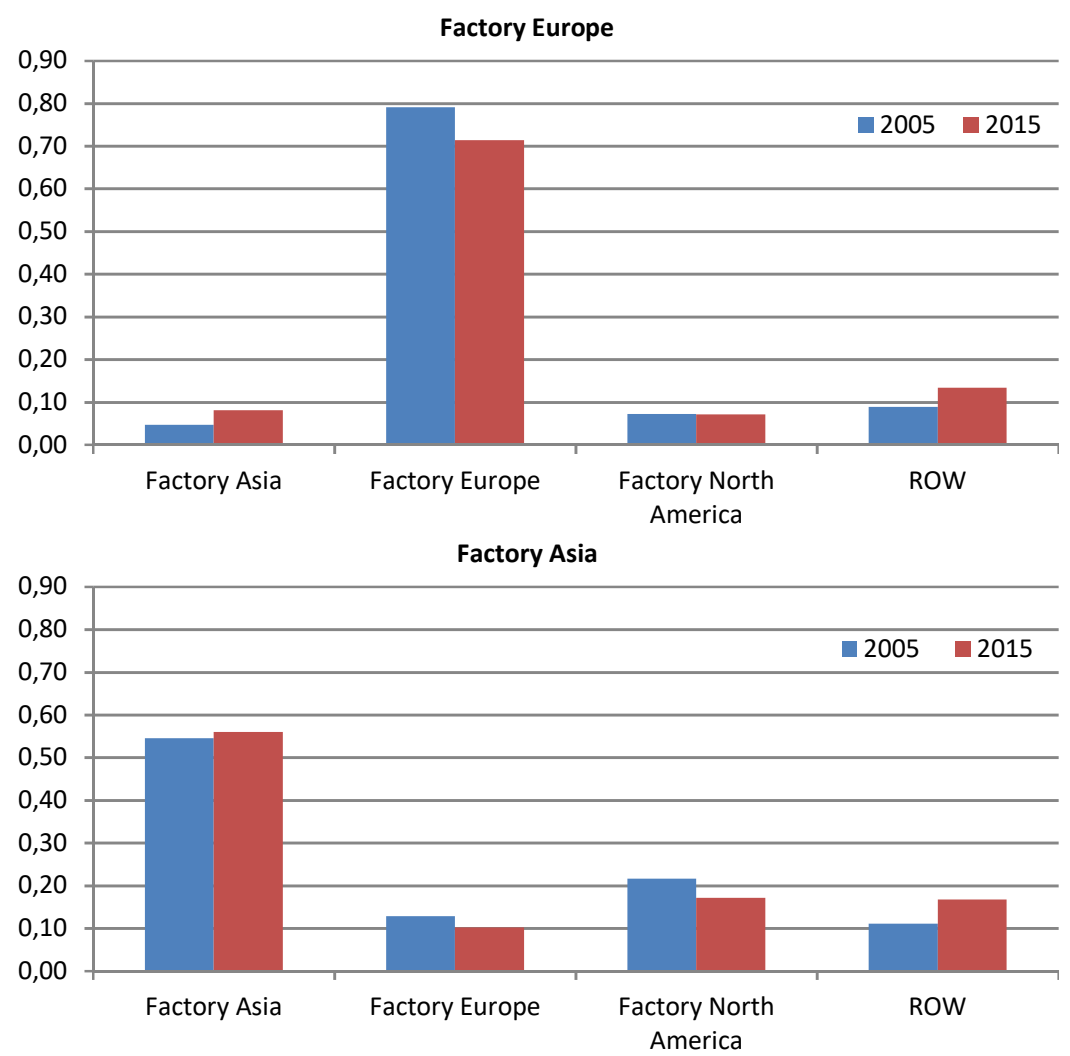

Factory North America

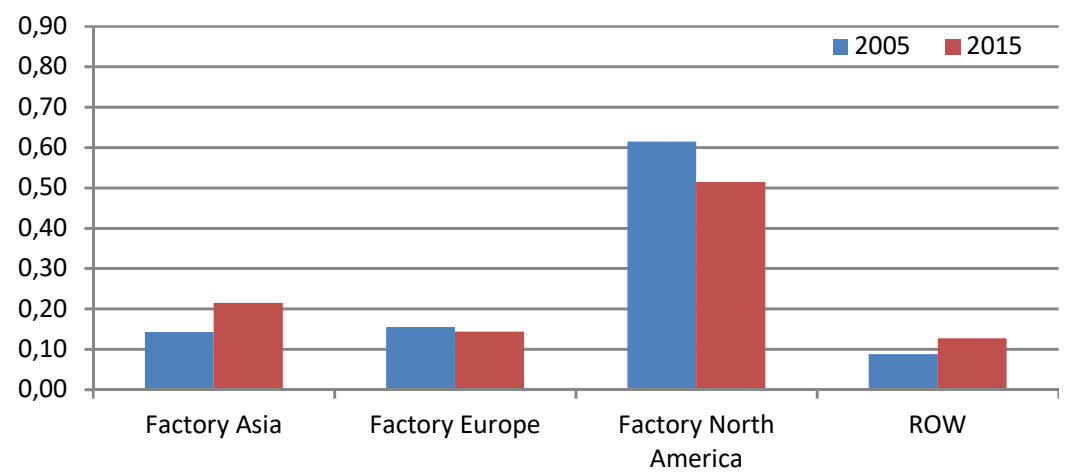

Figure 3. Share of intra-and inter-regional GVC participation in 2005 and 2015 Source: own elaboration based on (OECD, 2016).

Individual Factories participate in global value chains through regional supply hubs. In Europe and North America, they are Germany and the USA, respectively. In Asia, China currently plays a major role. In the analyzed period, China became the most significant partner in intra- and inter-regional domestic value added trade in intermediate products. 
Its role has grown not only in Asia, but it can be said that it is becoming a world supply hub.

The research is limited by access to statistical data. On the one hand, it should be remembered that the international input-output tables are generalized to some extent. On the other hand, geographical and, above all, temporal coverage prevents ongoing analysis. Further work on analyzing global production chains can be carried out in different directions. First of all, when newer statistics appear, it would be possible to check whether trends from 2005-2015 persist. Secondly, the participation and position of individual countries in the GVC is worth examining. And in the context of current changes in the global economy, such as the trade war between China and the US, or the COVID-19 pandemic, it might be interesting to see how global value chains are evolving. Has China maintained its position as a world supply hub?

\section{REFERENCES}

Ambroziak, Ł. (2018a). Determinanty handlu zagranicznego Polski mierzonego wartością dodaną. International Entrepreneurship Review/Przedsiębiorczość Międzynarodowa, 4(1), 9-22. https://doi.org/10.15678/PM.2018.0401.01

Ambroziak, Ł. (2018b). Wartość dodana w handlu zagranicznym nowych państw członkowskich unii Europejskiej. Oficyna Wydawnicza SGH.

Baldwin, R. (2008). Managing the Noodle Bowl: The Fragility of East Asian Regionalism. The Singapore Economic Review, 53(3), 449-478.https://doi.org/10.1142/S0217590808003063

Baldwin, R., \& Lopez-Gonzales J. (2015). Supply-Chain Trade: A Portrait of Global Patterns and Several Testable Hypotheses. The World Economy, 38(11), 1682-1721.https://doi.org/10.1111/twec.12189

Behar, A., \& Freund, C. (2011). Factory Europe? Brainier but not Brawnier. FREIT Working Paper, No. 312.

Folfas, P. (2016). Handel międzynarodowy mierzony wartościq brutto oraz wartościq dodanq - analiza porównawcza. Oficyna Wydawnicza SGH.

Fritsch, M., \& Matthes, J. (2020). On the global value chains and the intra-European division of labour. National Institute Economic Review, 252. https://doi.org/10.1017/nie.2020.16.

Gereffi, G., Humphrey, J., Kaplinsky, R., \& Sturgeon, T.J. (2001). The Value of Value Chains: Spreading the Gains from Globalisation. IDS Bulletin,32(3).

Inomata, S. (2017). Analytical frameworks for global value chains: An overview. In Global Value Chain Development Report 2017: Measuring and analyzing the impact of GVCS on economic development (pp. 15-35). International Bank for Reconstruction and Development/The World Bank.

Johnson, R.C., \& Noguera, G. (2012). Proximity and Production Fragmentation.. American Economic Review, 102 (3), 407-411. http://dx.doi.org/10.1257/aer.102.3.407

Kordalska, A., \& Olczyk M. (2019). Is Germany a Hub of 'Factory Europe' for CEE Countries? Ekonomista, 6, 734-759.

Koopman, R., Powers, W., Wang, Z., \& Wei, S.J. (2010). Give Credit Where Credit Is Due: Tracing Value Added in Global Production Chains. NBER Working Paper, 16426. DOI: 10.2139/ssrn.1949669

Li, X., Meng, B., \& Wang, Z. (2019). Recent patterns of global production and GVC participation. In Technical innovation, supply chain trade, and workers in a globalized world. Global Value Chain Development Report 2019 (pp. 9-44). World Trade Organization. 
Meng, B., Xiao, H., Ye, J., \&Li, S. (2019). Are global value chains truly global? A new perspective based on the measure of trade in value added. IDE Discussion Papers, No. 736.

Miroudot, S., \& Nordstrom, H. (2019). Made in the World Revisited. EUI Working Paper RSCAS, 2019/84. http://dx.doi.org/10.2139/ssrn.3489137

Organisation for Economic Co-operation and Development (2016). Trade in Value-Added and Global Value Chains profiles. Explanatory notes. http://www.oecd.org/industry/ind/ measuring trade in value-addedanoecd-wtojointinitiative.htm, access: 22.10.2016.

Organisation for Economic Co-operation and Development (2019). Guide to OECD's Trade in Value Added (TiVA) Indicators. 2018 edition. https://www.oecd.org/sti/ind/tiva/TiVA2018_Indicators_Guide.pdf, December 2019, access: 30.01.2020.

Organisation for Economic Co-operation and Development (2020). Trade in Value Added (TiVA). https://stats.oecd.org/, access: 30.01.2020.

Stehrer, R., Foster, N., \& Vries, G. (2012). Value Added and Factors in Trade: A Comprehensive Approach. WIIW Working Paper, 80, The Vienna Institute for International Economic Studies.

United Nations Conference on Trade and Development (2013). World Investment Report 2013: Global Value Chains: Investment and Trade for Development. United Nations.

World Trade Organization (2014). World Trade Report 2014. Trade and development: recent trends and the role of the WTO. World Trade Organization.

\section{Author}

\section{Aleksandra Nacewska-Twardowska}

Master of Economics (University of Lodz, Poland); PhD student in Economicś (University of Lodz, Poland). Her research interests include international trade, global value chains and economic integration.

Correspondence to: mgr Aleksandra Nacewska-Twardowska, University of Lodz, Institute of International Economics, Department of International Business and Trade, ul. POW 3/5, 90-255 Lodz, Poland, e-mail: Aleksandra.nacewska-twardowska@uni.lodz.pl

ORCID (1) http://orcid.org/0000-0002-8074-0361

\section{Copyright and License}

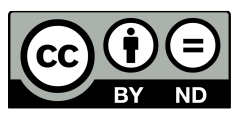

This article is published under the terms of the Creative Commons

Attribution - NoDerivs (CC BY-ND 4.0) License

http://creativecommons.org/licenses/by-nd/4.0/

Published by Cracow University of Economics - Krakow, Poland 